\title{
PENGARUH SISTEM PEMASARAN DIGITAL MARKETING TERHADAP PENINGKATAN VOLUME PENJUALAN HASIL INDUSTRI RUMAHAN
}

Theresia Pradiani

Dosen STIE ASIA Malang

\section{Abstrak}

Perkembangan teknologi informasi yang berkembang sangat pesat saat ini berpengaruh bagi masyarakat dalam mendukung berbagai kegiatan bisnis baik besar maupun kecil agar dapat dikenal secara global. Dampak yang paling nyata adalah selain dikenal juga dapat meningkatkan volume penjualan dan profit. Digital Marketing adalah salah satu media pemasaran yang sangat besar memberikan pengaruh. Dengan menggunakan digital marketing dalam hal ini adalah sosial media, ibu-ibu PKK di RW 02 Randuagung Singosari Malang memasarkan hasil indutri rumahan berupa kerajinan tangan tas dari bungkus minuman instan. Awalnya kegiatan ini hanya sebagai pengisi waktu luang, tetapi saat ini justru menjadi kegiatan utama sebagai penambah perputaran ekonomi dalam rumah tangga. Dahulu kegiatan penjualan hasil industri ini secara konvesional maupun tradisiona, mereka membuat produk hanya berdasarkan pesanan. Tetapi setelah mengenal adanya sosial media ibu-ibu PKK ini sudah mulai menerima banyak pesanan, sehingga volume penjualan semakin meningkat pesat dibandingkan saaat penjualan dengan cara lama. Digital marketing dipandang sebagai media yang paling baik sebagai sarana promosi yang paling efektif dan efisien serta mampu meningkatkan volume penjualan yang signifikan, dari pendapatan perbulan bersih Rp. 1.000.000,- s.d. Rp. 1.500.000,- sekarang bisa mencapai Rp. 2.000 .000 s.d. $3.500 .000,-(100 \%)$.

Kata Kunci : Digital Marketing, Volume Penjualan, Industri rumahan

\section{PENDAHULUAN}

Perkembangan teknologi informasi sangat berkembang pesat. Berbagai kegiatan bisnis kecil sampai besar memanfaatkan perkembangan ini untuk menjalankan usahanya. Banyaknya competitor menjadi pertimbangan bagi para pengusaha untuk masuk dalam persaingan yang sangat ketat. Strategi pemasaran dan media yang tepat digunakan untuk bisa meraih pasar yang dituju sehingga volume penjualan selalu meningkat dan profit. Digital Marketing adalah salah satu media pemasaran yang saat ini sedang banyak diminati oleh masyarakat untuk medukung berbagai kegiatan yang dilakukan. Mereka sedikit demi sedikit mulai meninggalkan model pemasaran konvesional/tradisional beralih ke pemasaran moderen yaitu digital marketing. Dengan digital marketing komunikasi dan transaksi dapat dilakukan setiap waktu/real time dan bisa mengglobal atau mendunia. Dengan jumlah pengguna social media berbasis chat ini yang banyak dan semakin hari semakin bertambah membuka peluang bagi UKM untuk mengembangkan pasarnya dalam genggaman smartphone.

Survei yang dilakukan sepanjang 2016 itu menemukan bahwa 132,7 juta orang Indonesia telah terhubung ke internet. Adapun total penduduk Indonesia sendiri sebanyak 256,2 juta orang. Hal ini mengindikasikan kenaikan 51,8 persen dibandingkan jumlah pengguna internet pada 2014 lalu. Survei yang dilakukan APJII pada 2014 hanya ada 88 juta pengguna internet. "Penyebabnya adalah perkembangan infrastruktur dan mudahnya mendapatkan smartphone atau perangkat genggam," terang Ketua APJII Jamalul Izza saat ditemui Kompas Tekno di sela pengumuman Riset Pengguna Internet Indonesia 2016, di Jakarta, Senin (24/10/2016), Kompas.

Seperti halnya yang saat ini sedang dilakukan oleh ibu-ibu PKK dalam memasarkan hasil industri rumahannya yaitu kerajinan tangan. Industri rumahan saat ini menjadi kegiatan yang memiliki peran besar dalam membantu perputaran ekonomi rumah tangga. Bentuk kegiatan industri rumahan bermacammacam, misalnya makanan, kerajinan, minuman dan lain-lain. Belum lama ini saya menemukan perkampungan di RW 02 Randuagung Singosari Malang, dimana di dalamnya para ibu rumah tangga, rata-rata membuat kerajinan tangan tas baik kecil sampai besar yang bahan bakunya dari sisa bungkus minuman kemasan instan seperti kopi, susu tas plastik belanja dari supermarket besar, dan lain-lain. Awalnya kegiatan ini hanya sebagai sambilan dan 
mengisi kesibukan, tetapi sekarang justru menjadi kegiatan yang bermanfaat dan menghasilkan. Kegiatan ini diawali oleh seorang ibu, istri dari dosen Perguruan Tinggi di Malang, yang memberikan pelatihan pada saat acara pertemuan PKK rutin di RW (Rukun Warga) setempat.

Pesanan dari kalangan teman dan kerabat dekat mulai muncul. Setelah berjalannya waktu, kegiatan ini menjadi kegiatan serius yang ingin dijalani oleh para ibu untuk menambah dan mendukung perekonomian di rumah tangga. Masalah yang timbul adalah bagaimana menetapkan strategi pemasaran yang tepat agar produk industri rumah tangga ini dapat cepat dikenal dan menerima pesanan secara luas, karena selama ini komunikasi dan transaksi yang terjadi masih menggunakan sistem konvesional maupun tradisional, dari mulut ke mulut dan karena kenal saja. Fenomena yang ada adalah bahwa lokasi kegiatan ini tidak berada di pinggir melainkan radius $500-1000 m$ dari jalan raya besar.

Dalam mendukung kegiatan tersebut, banyak ibu-ibu yang sudah menggunakan telpon genggam atau smartphone yang cukup moderen. Rupanya mereka juga sudah mengenal dan melakukan kegiatan pemasaran dengan memanfaatkan smartphone tersebut. Komunikasi yang dilakukan adalah dengan telepon langsung, sms (short message send), dan sudah mulai menggunakan social media untuk melakukan penawaran seperti BBM (blackbbery Mesangger), FB (Facebook), WA (Whatsapp), IG (Istagram). Berdasarkan alasan di atas penulis tertarik untuk melakukan penelitian apakah sosial media bagian dari digital marketing yang digunakan, memberikan pengaruh terhadap volume penjualan industri rumahan mereka. Dan Judul penelitian yang diangkat adalah PENGARUH SISTEM PEMASARAN DIGITAL MERKETING TERHADAP PENINGKATAN VOLUME PENJUALAN HASIL INDUSTRI RUMAHAN

\section{RUMUS AN MASALAH}

Mengacu dari latar belakang di atas maka secara umum rumusan masalah adalah bagaimana mengimplementasikan digital marketing, apakah berpengaruh dalam meningkatkan volume penjualan hasil industri rumahan.

\section{BATASAN MASALAH}

Banyak hal yang mempengaruhi peningkatan volume penjualan, promosi, periklanan, kualitas produk, harga dan lain-lain. Disamping itu dalam digital marketing juga ada social media dan search engine optimation (SEO). Dalam penelitian ini penulis hanya membatasi pada social media yang digunakan ibu-ibu PKK yang dapat memberikan pengaruh pada peningkatan volume penjualan. Karena SEO bersifat sangat teknis dan ibu-ibu PKK jarang menggunakannya. Sejauh ini ibu-ibu PKK hanya memanfaatkan smartphone yang dimiliki dan fitur-fitur yang sediakan oleh smartphone.

\section{TUJUAN}

Berdasarkan rumusan masalah di atas maka tujuan penelitian ini secara umum mendeskripsikan bagaimana mengimplementasikan digital marketing apakah dapat memberikan pengaruh terhadap peningkatan volume penjualan hasil industri rumahan ibu-ibu PKK.

\section{MANFAAT}

Secara umum manfaat dari penelitian adalah untuk mengetahui apakah digital marketing dapat memberikan pengaruh terhadap peningkatan volume penjualan dari hasil industri rumahan tersebut. Dan bagi penulis adalah sebagai suatu ekperimen untuk menambah wawasan yang dapat dipakai acuan untuk melakukan penelitian selanjutnya. Untuk ibu-ibu PKK RW bisa sebagai wacana baru agar semakin berinovasi dalam memasarkan hasil industri rumahannya.

\section{TINJAUAN PUSTAKA}

Turban et al. (2004), Katawetawaraks dan Wang (2011) menjelaskan bahwa belanja online adalah kegiatan pembelian produk (baik barang ataupun jasa) melalui media internet. Kegiatan belanja online meliputi kegiatan Business to Business (B2B) maupun Business to Consumers (B2C). Sementara pada penelitian kegiatan belanja online dikaitkan dengan B2C karena kegiatan pembelian yang dimaksudkan adalah kegiatan pembelian yang digunakan oleh konsumen sendiri, tidak dijual kembali. Kegiatan belanja online di sini adalah transaksi yang bersifat ritel dengan pembeli individu, sehingga belanja online di sini adalah sebuah keputusan pembelian yang dilakukan oleh individu secara online.

E-marketing di dalamnya (Chaffey, 2000). Sebenarnya e-marketing merupakan 
pengembangan dari marketing tradisional dimana marketing tradisional adalah suatu proses pemasaran melalui media komunikasi offline seperti melalui penyebaran brosur, iklan di televisi dan radio, dan lain sebagainya. Setelah maraknya internet dan kemudahan komunikasi yang ditawarkanya, maka penerapan marketing pada perusahaan mulai mengadopsi media internet, yang kemudian disebut sebagai e-marketing.

Sedangkan menurut Kotler dalam Widodo (2002) internet marketing memiliki lima keuntungan besar bagi perusahaan yang menggunakannya. Pertama, baik perusahaan kecil maupun perusahaan besar dapat melakukannya. Kedua, tidak terdapat batas nyata dalam ruang beriklan jika dibandingkan dengan media cetak dan media penyiaran. Ketiga, akses dan pencarian keterangan sangat cepat jika dibandingkan dengan surat kilat atau bahkan fax. Keempat, situsnya dapat dikunjungi oleh siapapun, dimanapun di dalam dunia ini, kapanpun. Kelima, belanja dapat dilakukan secara lebih cepat dan sendirian.

(Sarwono dan Prihartono:2012) mengemukakan bahwa teknik yang memudahkan akses dan publikasi informasi menggunakan interaksi social melalui social media. Kemudian Aloysius Bagas Pradipta Irianto dalam jurnalnya berjudul pemanfaatan social media untuk meningkatkan market share UKM menyampaikan, Pada saat ini terdapat dua jenis pemasaran, yaitu offline marketing atau pemasaran tradisional yang dilakukan dengan mencari pelanggan atau klien melalui pertemuan secara langsung berhadapan dengan mereka yang mungkin tertarik menjadi pelanggan atau klien. Pemasaran yang lain menggunakan situs web sebagai media pemasaran yang dikenal sebagai online marketing.

Dari sudut pandang bisnis, social media adalah tentang memungkinkan pembicaraan. Social media juga tentang cara pembicaraan ini bisa dihasilkan, dipromosikan, dan dijadikan pendapatan (Safko, 2009). Media sosial adalah tempat, alat bantu, layanan yang memungkinkan individu untuk mengekspresikan diri mereka untuk bertemu dan berbagi dengan rekan lainnya melalui teknologi internet. Social media adalah fase perubahan bagaimana orang menemukan, membaca, berbicara, dan membagi-bagikan informasi, berita, data kepada orang lain. Social media menjadi sangat populer karena kemudahan dan memberikan kesempatan kepada orang-orang untuk dapat terhubung secara online dalam bentuk hubungan personal, politik dan kegiatan bisnis.Social media menyediakan layanan komunikasi social. (Kartika, 2013):

Menurut Strauss dan Frost (2009), tujuh tahap dalam perancangan e-marketing adalah Situation Analysis (Analisis Situasi), EMarketing Strategic Planning (Strategi Perencanaan E-Marketing), Objectives (Tujuan), E-Marketing Strategy (Strategi EMarketing), Implementation Plan (Rencana Pelaksanaan), Budget (Anggaran), Evaluation Plan (Rencana Evaluasi). Adapun detil penjelasannya adalah :

1. Situation Analysis (Analisis Situasi) Tahap pertama merupakan awal dari konsep bisnis dengan melakukan analisis kekuatan, peluang, kelemahan serta ancaman bagi perusahaan. Dalam bagian ini, analisis situasi yang digunakan adalah analisis SWOT. Menurut Rangkuti (2004), analisis SWOT adalah indentifikasi berbagai faktor secara sistematis untuk merumuskan strategi perusahaan. Analis is ini disarankan pada logika yang dapat memaksimalkan Kekuatan (Strengths) dan Peluang (Opportunities), namun secara bersamaan dapat meminimalkan Kelemahan (Weaknesses) dan Ancaman (Threats). Proses pengambilan keputusan strategi selalu berkaitan dengan pengembangan misi, tujuan, strategi, dan kebijakan perusahaan. Dengan demikian perencanaan strategi (strategic planner) harus menganalisis faktor-faktor strategi perusahaan (kekuatan, kelemahan, peluang, dan ancaman) dalam kondisi yang ada saat ini. Hal ini disebut Analisis Situasi. Analisis SWOT membandingkan antara faktor internal Kekuatan (Strengths) dan Kelemahan (Weaknesses) dengan faktor eksternal Peluang (Opportunities) dan Ancaman (Threats) yang dihadapi dunia bisnis.

2. E-marketing Strategic Planning (Strategi Perencanaan E-marketing) Dalam tahap ini terdapat metodologi tujuh langkah sederhana yang membantu dalam mengevaluasi dan menganalisis peluang pasar (Market Opportunity Analysis/MOA), yaitu: Mengidentifikasi kebutuhan pelanggan yang belum terpenuhi mengidentifikasi 
pelanggan tertentu yang akan dituju oleh perusahaan. Menilai keuntungan yang berkaitan dengan kompetisi menilai sumber daya perusahaan untuk memberikan penawaran menilai kesiapan pasar akan teknologi. Menentukan peluang secara konkret. Menilai peluang daya tarik bagi pelanggan. Strategi perencanaan emarketing meliputi segmentation, targeting, differentiation, dan positioning

3. Objectives (Tujuan) Tujuan dalam $e$ marketing mencakup aspek tugas, kuantitas, dan waktu. Tugas (apa yang akan dicapai). Kuantitas yang terukur (seberapa banyak). Time frame (kapan). Sebagian besar e-marketing bertujuan untuk mencapai berbagai tujuan seperti berikut: Meningkatkan pangsa pasar. Meningkatkan jumlah komentar pada sebuah blog atau website. Meningkatkan pendapatan penjualan. Mengurangi biaya (misalnya biaya distribusi atau promosi). Mencapai tujuan merek (seperti meningkatkan kesadaran merek). Meningkatkan ukuran database. Mencapai tujuan Customer Relationship Management (CRM) (seperti meningkatkan kepuasan pelanggan, frekuensi pembelian, atau tingkat referensi pelanggan). Memperbaiki manajemen rantai suplai (seperti dengan meningkatkan koordinasi anggota, menambahkan mitra, atau mengoptimalkan tingkat persediaan).

4. E-marketing Strategy (Strategi Emarketing) Strategi e-marketing mencakup strategi mengenai 4P dan hubungan manajemen (relationship management) untuk mencapai tujuan rencana mengenai Product (Produk), Price (Harga), Place (Saluran Distribusi), dan Promotion (Promosi).

5. Implementation Plan (Rencana Pelaksanaan) Pada tahap ini perusahaan memutuskan bagaimana untuk mencapai tujuan melalui strategi yang efektif dan kreatif. Pemasar memilih bauran pemasaran (4 P), strategi manajemen dan strategi lain untuk mencapai tujuan rencana dan kemudian menyusun rencana pelaksanaan (Implementation Plan). Perusahaan juga memeriksa untuk memastikan organisasi pemasaran yang tepat di tempat pelaksanaan (staf, struktur departemen, penyedia layanan aplikasi, dan lain-lain di luar perusahaan). Internet telah mengubah tempat pertukaran dari marketplace (seperti, interaksi face-toface) menjadi marketspace (seperti, interaksi screen-to-face). Perbedaan utama adalah bahwa sifat hubungan pertukaran sekarang ditengahi oleh interface teknologi. Dengan perpindahan dari hubungan antar muka people-mediated menjadi technology-mediated, terdapat sejumlah pertimbangan perancangan interface yang dihadapi. Menurut Rayport dan J.Jaworski. (2003), ada berbagai elemen dalam mendesain sebuah situs web, yaitu context (konteks dari situs mencerminkan nilai keindahan dan kegunaan dari situs tersebut), content (konten merupakan semua objek digital yang terdapat dalam sebuah web baik dalam bentuk audio, video, image ataupun text), community (komunitas merupakan ikatan hubungan yang terjadi antara sesame pengunjung atau pelanggan dari sebuah website karena adanya kesamaan minat atau hobi), customization (kustomisasi merupakan kemampuan situs untuk memodifikasi dirinya sesuai dengan keinginan penggunanya), communication (komunikasi antara perusahaan dengan pelanggan, terdiri dari Broadcast Dimension, Interactive Dimension, dan Hybrid Dimension), connection (kemampuan sebuah website untuk berpindah dari sebuah webpage ke webpage lainnya ataupun website lainnya dengan onclick baik pada text, images maupun toolbars yang lain), dan commerce (commerce merupakan fitur dari customer interface yang mendukung berbagai aspek dari transaksi perdagangan dan memiliki dimensi seperti registration, shopping cart, security, credit card approval, one click shopping, order through affiliates, configuration technology, order tracking, delivery option).

6. Budget (Anggaran) Kunci dari perencanaan strategis adalah untuk mengidentifikasi hasil yang diharapkan dari suatu investasi. Selama pelaksanaan rencana, pemasar akan terus memantau pendapatan aktual dan biaya untuk melihat hasil yang telah dicapai. Internet merupakan salah satu tools yang dapat digunakan untuk memantau hasil karena catatan teknologi pengunjung setiap klik. Untuk mendapatkan informasi anggaran yang dapat dipertanggungjawabkan, perlu 
dibuat perhitungan tentang revenue forecast (perkiraan pendapatan), intangible benefits (manfaat tidak berwujud), cost savings (penghematan biaya), dan $e$ marketing costs (biaya emarketing).

7. Evaluation Plan (Rencana Evaluasi) Perencanaan e-marketing dilaksanakan, keberhasilannya tergantung pada evaluasi yang terus-menerus. Jenis evaluasi ini tergantung pada tujuan rencana. Untuk menentukan hasil pemasarannya, perusahaan dapat menggunakan balanced scorecard untuk mengukur kesuksesan dari program internet marketing dan apakah program internet marketing tersebut cocok sesuai dengan objektif dari perusahaan.

Penjualan adalah ilmu dan seni mempengaruhi pribadi yang dilakukan oleh penjual, untuk mengajak orang lain bersedia membeli barang atau jasa yang ditawarkan. Adapun volume penjualan adalah jumlah barang atau jasa yang terjual dalam proses pertukaran. (Basu Swatha: 2010) Volume penjualan dalam penelitian ini adalah jumlah produk yang terjual dalam penjualan yang dilakukan oleh Ibu-Ibu PKK.

Home industry adalah sebuah perusahaan yang anggota keluarganya secara langsung terlibat dalam kepemilikan dan jabatan atau fungsi. Bisnis keluarga mempunyai karakteristik dengan kepemilikannya atau keterlibatan lainnya dari dua peran atau lebih anggota keluarga yang sama dalam kehidupan dan fungsi bisnisnya. (Justin G. Longenecker, dkk:2001:35) Dalam hal ini dimaksudkan tentang usaha dan anggota keluarga yang berkecimpung di dalam usahanya. Pengertian usaha kecil ini sendiri tercantum dalam UU No 9 tahun 1995 yang di dalamnya menyebutkan, usaha kecil merupakan usaha dengan kekayaan bersih paling banyak Rp 200.000.000,- (tidak termasuk tanah dan bangunan tempat usaha) dengan hasil penjualan tahunan paling banyak Rp 1.000.000.000,-.(Arman Anwar:2015).

\section{METODOLOGI}

Metodologi dari penelitian ini dibagi dalam desain penelitian dan subyek penelitian, metode pengumpulan data dan metode analisis data.

1. Desain Penelitian dan Subyek Penelitian
Penelitian ini merupakan penelitian deskriptif observasional pada industri rumahan di RW 02 Randuagung Singosari Malang, menggunakan metode triangulasi, yang menggabungkan metode wawancara terstruktur, wawancara mendalam dan observasi terhadap Ibu-Ibu PKK dan media sosial yang digunakan. Subyek dalam penelitian ini adalah pengrajin yang dipilih secara purposive sampling. Subyek dipilih sesuai dengan kriteria: 1) merupakan pengrajin, 2) pernah menggunakan media sosial dalam komunikasi usahanya, 3) bersedia menjadi subyek penelitian. Total subyek yang direkrut dalam penelitian sebanyak 30 Orang.

2. Metode Pengumpulan Data

Penelitian ini menggunakan data primer yang diperoleh berdasarkan wawancara terstruktur dan wawancara mendalam kepada pengrajin. Data yang diperoleh meliputi data karakteristik umum, data penggunaan sosial media dalam industri rumahan, termasuk tujuan, manfaat dan hambatan yang dihadapi. Data dilengkapi dengan hasil observasi peneliti terhadap ibiibu PKK dan media sosial yang digunakan.

3. Analisis Data

Data yang diperoleh dianalisis menggunakan statistik deskriptif dan analisis kualitatif serta ditampilkan dalam bentuk table.

\section{HASIL DAN PEMBAHASAN}

Hasil dan pembahasan dari penelitian ini dibagi menjadi Karakteristik usaha industri rumahan yang menjadi subyek penelitian, penggunaan media sosial industri rumahan dan pengaruh penggunaana media sosial bagi industri rumahan.

\section{Karakteristik Industri Rumahan}

Subyek dalam penelitian ini adalah merupakan pengrajin yang membuat kerajinan tas dari bekas kemasan dan kantung plastic, dengan spesifikasi tas pesta dan tas kerja serta lamanya menjalani usaha industri rumahan. (Tabel 1)

Tabel 1. Karakteristik Usaha Industri Rumahan 


\begin{tabular}{|l|l|l|c|}
\hline No. & \multicolumn{1}{|c|}{ Karakteristik } & Jumlah & \% \\
\hline \multirow{3}{*}{1.} & Jenis Tas & & \\
\cline { 2 - 4 } & Tas dari Bekas Kantong Plastik & 20 & $66,67 \%$ \\
\cline { 2 - 4 } & Tas dari Bekas Kemasan Minuman & 10 & $33,33 \%$ \\
\hline \multirow{3}{*}{2} & Spesifikasi Tas & & \\
\cline { 2 - 4 } & Tas Pesta & 15 & $50 \%$ \\
& Tas Kerja & 15 & $50 \%$ \\
\hline \multirow{3}{*}{3.} & & & \\
\cline { 2 - 4 } & Lama Usaha & & \\
\cline { 2 - 4 } & 1-4 Tahun & 25 & $83,33 \%$ \\
& Di atas 4 tahun & 10 & $33,33 \%$ \\
& & 5 & $16,66 \%$ \\
& & & \\
\hline
\end{tabular}

\section{Penggunaan Media Sosial pada UKM}

Ibu-Ibu PKK dalam penelitian

ini, menggunakan media sosial sebagai media informasi dan komunikasi kegiatan usahanya. Rata-rata yang digunakan adalah, facebook dalam menampilkan profil perusahan. E-mail, Black Berry Messanger (BBM) dan WhatsApp (WA) dan Istagram (IG) untuk gambar-gambar produk. Hampir sebagian dari Ibu-Ibu PKK, menganggarkan dana sebesar Rp.100.000250.000,- untuk membeli pulsa sebagai sarana dalam pengelolaan media sosial sebagai informasi dan komunikasi usahanya. Bahkan mereka secara rutin selalu memperbaharui (update) informasi yang ditampilkan di media sosial setiap hari (Tabel 2)

Tabel 2: Media Sosial Yang Digunakan IbuIbu PKK

\begin{tabular}{|c|l|c|c|}
\hline No. & \multicolumn{1}{|c|}{ Variabel } & $\begin{array}{c}\text { Jumlah } \\
\mathbf{N}=\mathbf{3 0}\end{array}$ & Prosentase \\
\hline \multirow{2}{*}{1.} & Jenis Sosial Media Yang & & \\
& Digunakan & & \\
\cline { 2 - 4 } & BBM (blackbbery Mesangger) & 25 & $83,33 \%$ \\
& FB (Facebook) & 28 & $93,33 \%$ \\
& IG (Istagram) & 20 & $66.67 \%$ \\
& WA (Whatsapp) & 30 & $100 \%$ \\
\hline \multirow{2}{*}{2.} & Pengeluaran untuk Pulsa & & \\
\cline { 2 - 4 } & Rp. 50.000-100.000,- & 10 & $33,33 \%$ \\
& Rp. 110.000-200.000,- & 25 & $83,33 \%$ \\
& Rp.210.000-250.000,- & 5 & $16,66 \%$ \\
\hline 3 & Frekuensi Pembaharuan & & \\
& Informasi & 5 & $16,66 \%$ \\
\hline & Setiap Jam & 15 & $33,33 \%$ \\
\hline & Setiap Hari & 3 & $0,1 \%$ \\
\hline & Setiap Minggu & 2 & $0,06 \%$ \\
\hline & Setiap Bulan & & \\
\hline
\end{tabular}

\section{Pengaruh Penggunaan Media Sosial lbu- Ibu PKK}

Penggunaan media sosial bagi Ibu-Ibu

PKK sangat bermanfaat antara lain adalah, sebagai sarana kontak langsung dengan pemesan, sebagai sarana untuk mempromosikan hasil karya industry rumahan, mendata keinginan konsumen, menyampaikan respon ke konsumen dan sebagai dasar pengambilan keputusan dalam bertransaksi. Selain itu sosial media juga bermanfaat sebagai forum diskusi online, memantau perkembangan pelanggan, survei pelanggan, mendata kebutuhan penyalur/agen, menampilkan photo produk (Tabel 3)

Tabel .3 Manfaat Penggunaan Sosial Media Ibu-Ibu PKK

\begin{tabular}{|l|l|c|c|}
\hline No. & \multicolumn{1}{|c|}{ Manfaat } & Jumlah & $\%$ \\
\hline 1. & $\begin{array}{l}\text { Sarana kontak langsung dengan } \\
\text { pemesan }\end{array}$ & 30 & $100 \%$ \\
\hline 2. & Sarana untuk mempromosikan & 25 & $83,33 \%$ \\
\hline 3. & Mendata keinginan konsumen & 25 & $83,33 \%$ \\
\hline 4. & Menyampaikan respon ke konsumen & 20 & $66,67 \%$ \\
\hline 5. & $\begin{array}{l}\text { Sebagai dasar pengambilan } \\
\text { keputusan dalam bertransaksi }\end{array}$ & 30 & $100 \%$ \\
\hline 6. & Forum diskusi & 30 & $100 \%$ \\
\hline 7. & Memantauperkembangan pelanggan & 20 & $66,67 \%$ \\
\hline 8. & Survei pelanggan & 15 & $33,33 \%$ \\
\hline 9. & Mendata kebutuhan pelanggan & 20 & $66,67 \%$ \\
\hline 10. & Mendata kebutuhan penyalur/agen & 15 & $33,33 \%$ \\
\hline 11. & $\begin{array}{l}\text { Menampilkan photo produk hasil } \\
\text { industri }\end{array}$ & 30 & $100 \%$ \\
\hline
\end{tabular}

Ibu-ibu PKK sangat merasakan begitu besar manfaat yang diperoleh dengan menggunakan sosial media sebagai sarana kegiatan pemasran hasil industri rumahannya. Sosial media adalah salah satu unsur pendorong bagi Ibu-Ibu PKK untuk terus menggunakan dalam mengembangkan produk, melakukan komunikasi dengan konsumen dan pelanggan, penyalur, serta mengembangkan jaringan pasar yang lebih luas lagi, sehingga meningkatkan volume penjualan yang lebih besar. Hal ini seperti yang disampaikan oleh (Safko, 2009). Media sosial adalah tempat, alat bantu, layanan yang memungkinkan individu untuk mengekspresikan diri mereka untuk bertemu dan berbagi dengan rekan lainnya melalui teknologi internet. Social media adalah fase perubahan bagaimana orang menemukan, membaca, berbicara, dan membagi-bagikan informasi, berita, data kepada orang lain. Social media menjadi sangat populer karena kemudahan dan memberikan kesempatan kepada orang-orang untuk dapat terhubung secara online dalam bentuk hubungan personal, politik dan kegiatan bisnis. Social media menyediakan layanan komunikasi social. (Kartika, 2013): 
Selanjutnya, dibawah ini adalah table tentang penggunaan Social Media yang paling bermanfaat bagi ibu-ibu PKK di Tabel 4.

\section{Tabel .4 Penggunaan Social Media Yang}

Dirasakan Paling Bermnafaat

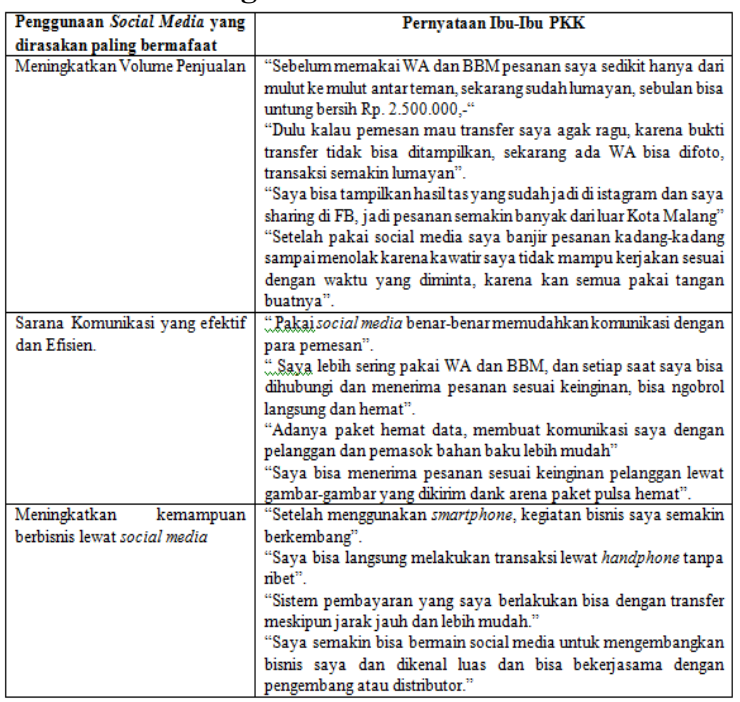

Dari hasil penelitian ini menunjukkan bahwa ibi-ibu PKK mendapatkan peningkatan pemesanan dari para konsumen setelah menggunakan social media. Disamping itu komunikasi juga efektif dan efisien karena bisa langsung berkomunikasi dan hemat. Kemudian mereka juga bisa mengembangkan bisnisnya lebih besar karena dapat bertransaksi langsung dan pembayaran juga bisa ditransfer, selain itu mampu mengembangkan bisnisnya dengan para agen/distributor.

Berikut nya bahwa akibat sosial media mengakibatkan terjadinya peningkatan volume penjualan Karena penilaian volume penjualan berdasarkan hasil wawancara dengan para ibuibu PKK secara cross sectional, sehingga dalam mengukur peningkatan volume penjualan sebelum dan sesudah menggunakan social media berdasarkan perkiraan hasil akhir perbulan.

\section{KESIMPULAN DAN SARAN Kesimpulan}

Kesimpulan yang bisa ditarik dari penelitian ini adalah, ibu-ibu PKK menggunakan social media sebagai sarana untuk menjalani indutri rumahannya. Media sosial yang paling banyak digunakan adalah Facebook (FB), Whatsaap (WA), Istagram (IG), Blacberry Message (BBM). Manfaat yang paling dirasakan adalah komunikasi dengan para pelanggan dan pemasok lebih intestif serta efektif dan efisien, karena dapat berkomunikasi langsung selama $24 \mathrm{jam} / \mathrm{real}$ time. Proses transaksi lebih mudah dan murah karena media komunikasi hanya mengeluarkan biaya pulsa untuk mendukung komunikasi. Media promosi yang paling baik karena bisa menampikan dan berbagi gambar lewat media ke komunitas dan masyarakat. Update informasi dapat dilakukan setiap waktu. Dan yang paling penting peningkatan volume penjualan rata-rata $100 \%$.

Saran

Ibu-ibu PKK disarankan lebih mengoptimalkan perkembangan teknologi informasi yang ada dengan maksimal. Artinya mulai melakukan inovasi-inovasi baru cara mempromosikan hasil industri rumahanya agar lebih menarik dengan memanfaatkan social media yang ada agar peningkatan volume penjualan secara continue bisa meningkat dan berkembang.

\section{DAFTAR PUSTAKA}

1. Arman Anwar, " Pengertian Home Industry” (online)

(http://ketrampilanhomeindustry. blogspot.com/2009/07/pengertian-homeindustry.html di akses pada tanggal 2 Pebruari 2017.

2. Chaffey, Dave, Richard Mayer, Kevin Johnston dan Fiona Ellis-Chadwick, 2000, Internet Marketing: Strategy, Implementattion And Practice, Pearson Education Limited, London, England.

3. Justin G. Longenecker, dkk., Kewirausahaan Manajemen Usaha Kecil, 2001, Salemba Empat, Jakarta.

4. Rayport, Jeffrey F. dan Bernard J.Jaworski, 2003, Introduction To E-Commerce, 2nd Edition, McGraw-Hill, New York.

5. Kotler, Philip dan Gary Amstrong, 2004, Principles of Marketing, 10th Edition, Pears on Education Inc. Upper Saddle River, New Jersey.

6. Kartika H, Bambang. WeChat, Social Messaging dengan Fitur Kaya Multimedia. www.chip.co.id, diakses pada 2 Pebruari 2017.

7. Katawetawaraks, C. \& Cheng, L. W. (2011). Online shopper behavior: Influences of online shopping decision. Asian Journal of Business Research, 1 (2), 66-74 
8. McLeod, Raymond dan George Schell, 2001, Management Information Systems, 8th Edition, Prentice Hall, Newn Jersey.

9. Rangkuti, F. (2010). Analisis SWOT teknik membedah kasus bisnis, Gramedia Pustaka Umum, Jakarta.

10. Jonathan Sarwono , K. Prihartono Perdagangan Online: Cara Bisnis di Internet, 2010, Elex media Komputindo, Jakarta.

11. Safko, Lon and David K.Brake 2009. The Social Media Bible: Tactics, Tools, and Strategies for Business Success, John Wiley \& Sons: New Jersey.

12. Strauss, Judy dan Raymond Frost, 2009, EMarketing, 5th Edition, Prentice-Hall, Inc., Upper Saddle, New Jersey.

13. Turban, Efraim, R.Kelly Jr.Rainer dan Richard E.Potter, 2005, Introduction To Information Technology, $3^{\text {rd }}$ Edition, John Wiley \& Sons, Inc., New York. 